\title{
Pesantren Muadalah Mathali'ul Falah Kajen Margoyoso Pati
}

\section{Oleh : M. Murtadho}

\section{Kampung Santri Bernama Kajen}

Kajen adalah sebuah Kampung santri yang berada di sekitar jalur Pantura, tepatnya beralamatkan di Kecamatan Margoyoso, Kabupaten Pati, Jawa Tengah. Dari ibukota Pati, Kajen berjarak kurang lebih 18 KM ke utara. Kalau kita ke sana dari arah Semarang, kita bisa naik Bus jurusan Surabaya turun di terminal Pati. Dari terminal Pati kita bisa naik bus jurusan Tayu turun di Desa Kajen, atau kendaraan kecil lainnya seperti ojek untuk mengantar sampai ke desa Kajen.

Desa Kajen adalah desa yang sudah padat penduduknya, sekalipun di luar desa masih membentang sawah yang luas. Luas tanah Desa Kajen sekitar 66.660 ha (0.65 $\mathrm{km} 2$ ) yang terdiri dari 4.710 ha tanah tegalan dan sisanya adalah tanah pekarangan dan bangunan rumah penduduk. Desa Kajen berada di tengah-tengah antara desa Waturoyo dengan Desa Ngemplak. Secara administrasi pemerintahan, desa Kajen berbatasan dengan desa Ngemplak Kidul (sebelah Selatan), Desa Sekar Jalak (Sebelah Timur), Desa Waturoyo (sebelah Utara).

Desa Kajen terdiri dari 11 Rukun Tetangga, dan 2 Rukun Warga. Desa ini mempunyai penduduk asli kurang lebih 3700 jiwa. Mata pencaharian penduduk beragam, ada petani, buruh, pedagang makanan untuk para santri, ada yang membuka warung internet dan sebagainya. Masyarakat Kajen lebih memahami tercukupinya kebutuhan hidup mereka lebih banyak dipengaruhi oleh keberkahan tempat itu. Dengan banyaknya santri yang belajar di tempat itu, banyaknya tamu berziarah ke makam KH Mutamakkin membuat ruang usaha kecil-kecilan terbuka bagi mereka. Fakta ini membedakan dengan Desa Ngemplak di sebelahnya yang banyak menekuni pembuatan Tepung Tapioka dan bidang perdagangan di sepanjang jalan di Ngemplak.

Di desa Kajen ini terdapat kurang lebih 40 pesantren. Hampir setiap rumah adalah tempat mukim para santri. Ada kurang lebih 7000 santri yang mukim di daerah itu. Sejarah Kajen mulai menjadi kampung santri adalah sejak H. Mutammakin mengembangkan pendidikan agama di wilayah itu. Di antara para kiai, santri, dan masyarakat tercipta hubungan simbiosis mutualisme sedemikian rupa sehingga Kajen sangat memenuhi syarat untuk disebut sebagai kampung santri. Tidak ada konflik terbuka antar kiai, juga tidak ada kesan persaingan antar satu pesantren dengan pesantren lainnya. 
Di antara pesantren yang banyak itu ada sebuah lembaga pendidikan keagamaan yang cukup menjadi pemersatu, yaitu Perguruan Islam Mathali'ul Falah (berdiri 1912). Sebuah lembaga pendidikan yang mengajarkan 70 persen pelajaran agama dan pelajaran umum 30 persen. Semua santri dalam banyak pesantren itu banyak yang menempuh pendidikan agama di Mathali'ul Falah tersebut.

Selain Mathali'ul Falah terdapat beberapa lembaga pendidikan lainnya yang melayani para santri di desa tersebut seperti lembaga pendidikan formal Madrasah Salafiyah (MI, MTs dan MA), Perguruan Islam Al Hikmah (MI, MTs dan MA), PGIP, STAIMAFA. Selain itu ada beberapa lembaga pendidikan yang ada di desa sebelah seperti Khoiriyah (Waturoyo), Darun Najah (Ngemplak), Manabiul Falah (Ngemplak). Semua lembaga itu saling melayani tanpa menimbulkan konflik interest satu dengan lainnya.

Selain banyaknya pesantren dan lembaga pendidikan, keberadaan makam perintis pendidikan Islam di Kajen KH Mutamakkin juga banyak diziarahi oleh umat dari berbagai tempat. KH Mutamakkin dianggap oleh masyarakat sebagai seorang waliyullah, sehingga makamnya setiap hari tidak pernah sepi dari peziarah. Sebagai daerah kunjungan, sekitar makam KH Mutamakkin banyak dibuka lapak-lapak pedagang yang mencari keuntungan dari para peziarah yang datang. Keberadaan makam ini menjadi magnet tersendiri untuk memanggil orang dari segala penjuru datang ke wilayah ini.

Kepemimpinan kampung santri Kajen telah berganti-ganti. Terakhir pesantren Kajen sangat terkenal dengan sosok KH Sahal Mahfudz yang dikenal sebagai penggagas Figh Sosial. Sepeninggal KH Sahal Mahfudz, kiai yang disegani secara nasional pada tahun 2014, pelanjut beliau untuk komunitas pesantren di desa Kajen adalah kyai yang dituakan di Kajen yaitu KH Nafi' Abdillah. Proses estafeta itu berjalan secara otomatis tanpa ada penunjukkan, siapa yang dianggap sepuh dan pengayom akan otomatis dituakan oleh para kyai di desa tersebut. Sementara Pesantren Matholiul Huda, pesantren yang dulu diasuh oleh KH Sahal diteruskan oleh putranya, yaitu Abdul Ghaffar Rozien, M. Ed.

Satu hal yang menarik lainnya adalah sekalipun secara kultural semua warga Kajen menganut paham keagamaan Ahlu sunnah wal Jamaah dengan identifikasi ke organisasi kemasyarakatan Nahdlatul Ulama (NU), namun ketika musim kampanye Pemilu baik nasional maupun Pilkada tidak diperkenankan satu bendera partai pun berkibar di desa ini. Bendera Partai Kebangkitan Bangsa yang berlatar belakang massa Nahdliyin juga tidak diperbolehkan dipasang, apalagi partai lain. Dalam sikap politik, pesantren-pesantren Kajen memilih netral. 
Semua ini dalam bacaan penulis menjadi modal penting bagi Desa kajen sehingga pantas desa ini menjadi pusat spiritual tersendiri untuk daerah Jawa Tengah. Cara pandang pesantren yang tidak menggantungkan diri pada pemerintah dalam menyelenggarakan pendidikan, fokus kepada tafaqqu fiddin, tidak berpolitik, menggagas hidup mandiri menjadi kekuatan yang tidak tertandingi atau paling tidak tidak mudah dipengaruhi untuk kepentingan apapun selain untuk mengembangkan ilmu agama. Beberapa prasyarat saling melengkapi untuk membangun budaya akademis untuk mengembangkan ilmu agama.

\section{KH Abdussalam Mathali'ul Falah: Pendiri Pesantren}

Kehadiran Pesantren Mathali'ul Falah di Kajen tidak lepas dari sosok KH Abdussalam. la adalah ulama Kajen Margoyoso Pati yang sekaligus menjadi perintis pertama madrasah pertama Jawa Tengah bagian Utara. Pada tahun 1912, KH Abdussalam merintis lembaga pendidikan yang dikenal sebagai Madrasah Arab di Kampung Kajen. Lembaga pendidikan inilah yang nantinya menjadi cikal bakal keberadaan Perguruan Islam Mathali'ul Falah (PIMF), perguruan terbesar di desa Kajen.

Abdussalam lahir dari orang tua bernama KH Abdullah. KH Abdullah adalah cicit dari KH Mutamakkin, seorang ulama kontroversial di zaman Raja Amangkurat IV di Surakarta, dan diabadikan kejadiaanya dalam Serat Cebolek. Namun setelah terjadi perdebatan dengan ulama kerajaan, Ketib Anom, maka KH Mutammakin dinyatakan tidak bersalah dan bahkan kemudian tanah desa Kajen dinyatakan sebagai tanah perdikan, yaitu tanah yang bebas dari pajak. Maka sejak itu, kampung Kajen dikenal sebagai Kampung Santri. Saat ini Desa Kajen terdiri dari kurang lebih 50 pesantren.

Silsilah Abdussalam hingga ke KH Mutamakkin adalah; Abdussalam bin $\mathrm{KH}$ Abdullah bin Nyai Mutiroh binti KH Bunyamin bin Nyai Thoyyibah binti K. Muhammad Hendro Kusumo bin KHMutamakkin. Dari keturunan KHMutamakkin, tradisi pesantren mulai berkembang sejak zaman KH Ismail (cucu menantu KH Mutammakin). Sejak itu lembaga pesantren bermunculan di desa Kajen yang didirikan oleh para keturunan KH Mutamakkin dan santri-santri lulusan pesantren yang berdomisili di desa Kajen.

Abdussalam adalah seorang hafidz (penghapal) Al-Qur'an. Namun kemampuan Abdussalam menghapal Al- Qur'an ditempuhnya bukan selagi muda, namun justru ketika beliau sudah tua. Dia terdorong menghapal Al-Qur'an dimulai ketika dia melihat model pengajaran yang diterapkan oleh salah satu kiai penghapal Al-Qur'an di pesantrennya, yaitu Kiai Hasbullah, terkesan keras. Maka sejak itu Abdussalam bertekad untuk menjadi penghapal Al-Qur'an dan mengajarkan sendiri nantinya kepada para santri-santrinya. 
Sebelum mendirikan madrasah Arab pada tahun 1912, Abdussalam terlebih dahulu mendirikan pesantren Mathali'ul Huda di Polgarut Selatan pada tahun 1910. Gagasan mendirikan madrasah Arab didorong oleh sikap Belanda yang mencurigai lembaga pendidikan pesantren. Maka untuk mengelabuhi Belanda, Abdussalam mengubah sistem pendidikannya ke arah pendidikan dengan model formal. Dan untuk membangun kesan formal, Abdussalam mengundang seorang guru bernama Pak Karto untuk mengajar pelajaran-pelajaran umum di Madrasah Arab pada tahun 1916.

Abdussalam adalah putra Kajen yang mendambakan bahwa Kajen suatu saat menjadi pusat pendidikan dan kiblat pengetahuan dan akhlak. Karena itu selain dia merintis pesantren dan madrasah Arab, dia juga mendorong saudara-saudaranya di Kajen untuk memperdalam ilmu agama baik di pesantren lain di Jawa atau ke Timur Tengah dan pulang mendirikan pesantren juga, seperti KH Mukhtar (Pendiri Pesantren Buludana), KH Hasbullah (Pendiri Pesantren Kauman). Maka cita-cita itupun saat ini sudah terwujud, ada kurang lebih 50 pesantren tersebar di desa Kajen. Di antara pesantren yang banyak itu, Madrasah Mathali'ul Falah atau sekarang disebut Perguruan Islam Mathali'ul Falah (PIMF) berada di tengah-tengah menjadi tempat pendidikan reguler dari semua pesantren yang ada di Kajen.

Dalam menggagas kampung Kajen sebagai kampung santri dan mewujudkan lembaga pendidikan Mathali'ul Falah, KH Abdussalam ditemani saudara kandungnya, KH Nawawi. Keduanya saling bahu-membahu. Keduanya juga masing-masing memiliki pesantren, kalau KH Abdussalam mempunyai pesantren Mathali'ul Huda di Polgarut Selatan, maka KH Nawawi juga memiliki pesantren Kulon Banon. Khusus KH Nawawi, dia memiliki kelebihan ilmu dalam hal kesaktian tertentu.

Untuk menyempurnakan model pendidikan yang digagasnya, $\mathrm{KH}$ Abdussalam mengirimkan anaknya Mahfudz Salam untuk menimba ilmu di pesantren Termas. Pesantren Termas saat itu dikenal sebagai salah satu pesantren yang membawa pengaruh besar bagi perkembangan pendidikan Islam di tanah Jawa. Maka dikirimlah Mahfudz Salam ke Pesantren ini. setelah menyelami pendidikan pesantren, kembali KH Abdussalam menugaskan Mahfudz Salam untuk mengetahui model pendidikan yang digagas oleh $\mathrm{KH}$ Hasyim Asy'ari di Jombang. Tidak cukup di dua lembaga pendidikan itu, Mahfudz Salam pun di kirim ke Mekah untuk menambah ilmu dan menuanikan rukun Islam yang kelima (Haji) ke Saudi Arabia.

Sepulangnya Mahfudz Salam dari Mekah tahun 1922, Abdussalam mengizinkan Mahfudz untuk mengambil langkah-langkah pembaruan di bidang pendidikan Islam. Maka sejak itu lembaga 'madrasah Arab' itu berganti nama menjadi Madrasah Mathali'ul Falah dan menerapkan pendidikan dengan sistem klasikal dengan kurikulum yang sistematis, gradual dan fungsional. 


\section{Program Muadalah Mathali'ul Falah}

Perguruan Islam Mathali'ul Falah (PIM) terletak di desa Kajen, kecamatan Margoyoso, kabupaten Pati, Jawa Tengah. Tepatnya di daerah Kulon Banon, sebelah barat makam KH. Ahmad Mutamakkin. Perguruan ini didirikan oleh KH. Abdussalam pada tahun 1912, dengan tujuan untuk mendidik dan mempersiapkan kader-kader bangsa sebagai insan yang memahami agama secara mendalam (tafaqquh fi ad-din) baik secara teori maupun praktik, sehingga bisa berperan aktif dalam kehidupan berbangsa dan bernegara (solih) dalam semangat ketuhanan yang luhur dan terpuji sebagaimana dicontohkan oleh baginda Nabi Muhammad SAW (akrom). Tujuan inilah yang sampai sekarang dijadikan sebagai pijakan dan visi utama dari penyelenggaraan pendidikan di Perguruan Islam Mathali'ul Falah (PIM).

Perguruan ini mengalami banyak perkembangan selama kurun waktu 1 abad ini (1912-2012). Pada tahun awal berdirinya (1912) ketika dipimpin oleh KH. Abdussalam, Perguruan ini dikenal dengan nama "Sekolah Arab". Kemudian pada masa berikutnya ketika dipimpin oleh KH. Mahfudh Salam (1922 - 1944) Perguruan ini diberi nama 'Mathali'ul Falah' (tempat munculnya orang-orang yang sukses) dengan kurikulum klasikal dari shifir awal, tsani dan tsalis. Pada masa kepemimpinan KH. Abdullah Zen Salam dan KH. Muhammadun Abdul Hadi (1945 - 1963) mulai dikembangkan sistem penjenjangan dari kelas 1-6 dan 1-3 Tsanawiyah. Kemudian di era selanjutnya di bawah kepemimpinan KH. Sahal Mahfudh (1967 - 2014) dikembangkan lagi menjadi Aliyah dan Diniyah Ula dan Wustha. Pendirian Diniyah ini dimaksudkan untuk menampung lulusan SD (Sekolah Dasar) dan SMP (Sekolah Menengah Pertama) dengan materi agama khusus. Sepeninggal KH Sahal Mahfudz, mulai tahun 2014 perguruan ini dipimpin oleh $\mathrm{KH}$. Ahmad Nafi' Abdillah.

Perguruan Islam Mathali'ul Falah bernaung di bawah badan hukum Yayasan Nurussalam beralamatkan di Kajen Margoyoso Pati. Perguruan ini telah menggunakan sistem kelas sudah dimulai sejak awal berdirinya lembaga pendidikan ini, pada tahun 1912. Pada tahun 1922, sistem kelas itu disempurnakan oleh putra pendiri, yaitu KH Mahfudz Salam. Dari jejaknya, model pendidikan Matholiul Falah bisa disebut sebagai perintis model madrasah di Jawa Utara, mengimbangi munculnya rintisan madrasah di Jawa Bagian Selatan seperti Muhammadiyah di Yogyakarta dan madrasah di Solo.

Model pendidikan ini sebenarnya sudah mendapat pengakuan dari beberapa lembaga pendidikan di luar negeri, namun sayangnya justru muadalah mulai diakui oleh pemerintah hingga tahun 2003. Baru setelah tahun 2003, pesantren Mathli'ul Falah jenjang Madrasah Aliyah ini terdaftar sebagai pesantren muadalah. Sejak itu lulusan pesantren Matholiul Falah bisa dengan mudah diterima di berbagai pendidikan tinggi di dalam negeri seperti STAIN, IAIN dan UIN. 
Saat ini bertindak sebagai pimpinan penyelenggaraan program muadalah ini adalah KH Nafi' Abdillah. Program ini mendasarkan pada tujuan yang sekaligus menjadi visi Mathali'ul Falah yaitu "untuk meraih nilai-nilai keislaman dengan Tafaqquh fiddin dan berikhtiar untuk menjadi Insan Solih Akrom."

Solih adalah manusia yang secara potensial mampu berperan aktif, berguna, dan terampil dalam kehidupan sesama makhluk, serta mampu mewarisi dan mengatur bumi ini dengan segala alam yang ada padanya, atau dengan kata lain yang mampu menguasai segala aspek kehidupan di masa kini dan di masa yang akan datang. Sedangkan Akrom merupakan pencapaian kelebihan dalam relevansinya dengan makhluk terhadap Khaliq, mencapai kebahagiaan di akhirat.

Visi itu diterjemahkan dalam beberapa misi: 1) membangun lembaga pendidikan yang berorientasi pada pengembanan tafaqquh fi ad-Din; 2) mempersiapkan peserta didik menjadi insan Solih Akrom; 3) Mencerdasakn kehidupan bangsa dan mengembangkan manusia Indonesia seutuhnya; 4) memberikan bekal peserta didik dalam menatap perkembangan ilmu pengetahuan dan teknologi.

Pendidikan di Perguruan Islam Mathali'ul Falah (PIM) dimaksudkan untuk mempersiapkan peserta didikmenjadi mampu mendalami, menghayati, mengamalkan, dan mengembangkan Islam secara utuh, serta mampu mengelola lingkungan.

Tujuan Khusus Pendidikan di Perguruan Islam Mathali'ul Falah (PIM) menitiktekankan pada penyiapan peserta didik: 1) Memiliki nilai-nilai keulamaan; 2) Mampu menguasai dasar-dasar ilmu Islam; 3) Mampu mendalami ilmu-ilmu fiqh; 4) Memiliki kepedulian terhadap kegiatan nasyru al-'ilmi; 5) Memiliki kepekaan terhadap kemaslahatan umat; 6) Mampu menerapkan pola hidup sederhana; 7) Memahami nilai-nilai estetika.

Mathali'ul Falah membuka program pendidikan jenjang madrasah Ibtidaiyah, Madrasah Tsanawiyah dan Madrasah Aliyah. Masing-masing jenjang mencapai target khusus meliputi:

Madrasah Ibtidaiyah dimaksudkan agar peserta didik menguasai dasar-dasar ilmu agama Islam, ilmu sosial, ilmu bahasa dan penalaran serta ilmu pengetahuan akhlak, sehingga mempunyai akidah yang benar, sadar untuk melakukan perilaku peribadatan dan pergaulan yang berakhlakul karimah.

Madrasah Tsanawiyah dimaksudkan agar peserta didik mengembangkan secara kualitatif maupun kuantitatif terhadap penguasaan dasar-dasar ilmu agama Islam, ilmu sosial, ilmu bahasa, ilmu pengetahuan dan penalaran

Pendidikan tingkat Aliyah dimaksudkan agar peserta didik dapat meningkatkan penguasaan dasar-dasar dan pengembangan ilmu agama Islam, ilmu sosial, ilmu 
bahasa, ilmu pengetahuan dan penalaran sehingga tercipta tujuan persiapan peserta didik menjadi manusia yang solih dan akrom dengan ciri-ciri berperilaku keulamaan, berkepedulian terhadap nasyrul 'ilmi dan kemaslahatan umat serta mampu mengembangkan dasar-dasar ilmu agama Islam.

\section{Tradisi Pendidikan Mathali'ul Falah}

Perguruan Mathali'ul Falah memegang prinsip mempertahankan tradisi lama yang baik dan mengambil sesuatu yang baru yang lebih baik (Al-Muhafadhah ala al- Qadim ash-Shalih wa al-Akhdzu bial-Jadid al-Ashlah). Kaidah yang sangat populer di kalangan pesantren ini merupakan salah satu kaidah yang terus dipegang oleh Perguruan Islam Mathaliul Falah (PIM) dalam menyelenggarakan pendidikan. Dengan berpedoman pada kaidah tersebut, maka PIM tetap berusaha untuk mempertahankan dan melestarikan tradisi-tradisi pesantren yang dipandang sebagai tradisi baik sehingga tidak hilang ditelan zaman, di samping juga tidak lupa untuk terus mengembangkan diri dalam menghadapi pekembangan zaman. Beberapa tradisi pendidikan pesantren yang masih dipertahankan oleh PIM hingga sekarang adalah; hapalan kitab, tes kitab, tes al-Qur'an, dan karya tulis bahasa Arab.

\section{Hapalan Kitab}

Hapalan merupakan syarat wajib kenaikan kelas di Perguruan Islam Mathaliu'l Falah (PIM), mulai dari kelas tiga ibtidaiyah sampai kelas satu aliyah. Kitab-kitab yang dihapalkan telah ditetapkan oleh PIM, seperti; kitab al-Arba'in an-Nawawiyah, alAmtsilah at-Tashrifyah, Tashilu al-Turuqat, Alfiyah ibnu Malik, matan Jauhar al-Maknun, Sullam al-Munawraq, dll. Karena menjadi syarat wajib, maka jika ada siswa yang tidak menghapalkan meskipun memiliki nilai yang cukup, tetap tidak bisa naik kelas.

Kewajiban hapalan ini terus dipertahankan hingga sekarang sebab hapalan bisa memberikan pendidikan pada siswa terhadap nilai-nilai tertentu yang baik, seperti rasa taggung jawab, istiqamah, kemandirian dan sebagainya, di samping juga bisa menjadi media untuk melatih kemampuan peserta didik dalam bidang kecepatan mereproduksi kesan, berpikir kritis, dan keberanian mental, yang pada gilirannya diharapkan mampu menunjang keberhasilan proses pembelajaran.

\section{Tes Kitab}

Tes kitab adalah membaca kitab "gundul" dan memberi makna dengan disimak oleh para guru PIM maupun para kiai sekitar Kajen. Tes kitab ini menjadi syarat kelulusan bagi kelas-kelas akhir pada jenjang Tsanawiyah dan Aliyah, yaitu kelas tiga Tsanawiyah dan tiga Aliyah. Materi tes kitab pada tingkat Tsanawiyah yaitu Fath 
al-Qarib (fiqh) dan Fath al-Majid (tauhid). Sedangkan materi tes kitab pada tingkat Aliyah adalah al-Jalalain (tafsir), Bulugh al-Maram (hadits), Tahrir (fiqih), dan Ghayat al-Wushul (ushul fiqh).

\section{Tes Al-Qur'an}

Seperti halnya tes kitab, tes membaca Al-Qur'an dengan benar juga menjadi syarat kelulusan di Perguruan Islam Mathali'ul Falah (PIM). Namun tes Al-Qur'an hanya diwajibkan bagi mereka yang sudah kelas tiga Aliyah saja.

\section{KTA (Karya Tulis Arab)}

KTA adalah membuat karya tulis dengan menggunakan bahasa Arab. KTA ini menjadi syarat wajib bagi siswa kelas tiga Aliyah untuk bisa mengikuti ujian catur wulan kedua. Tanpa membuat karya tulis bahasa Arab maka seorang siswa kelas tiga Aliyah tidak bisa mengikuti ujian catur wulan kedua.

KTA ini mulai diwajibkan sejak tahun 1998 M. Program ini dimaksudkan untuk mengembangkan dan melestarikan budaya tulis di kalangan pesantren yang mulai surut. Dengan program ini diharapkan budaya serta kemampuan tulis siswa meningkat dan pada gilirannya nanti bisa menghasilkan karya-karya yang bermanfaat. Setelah penulisan KTA selesai, ada juga ujian KTA (munagasyah) untuk mengetahui sejauh mana penguasaan siswa terhadap apa yang ditulisnya serta sebagai pertanggungjawaban terhadap apa yang ditulisnya. Disinilah nilai-nilai amanah serta tanggungjawab ditanamkan.

\section{Sarana Prasarana}

Perguruan Islam Mathali'ul Falah memiliki enam bangunan di atas areal 3150 meter, 50 ruang kelas dengan daya tampung masing-masing kelas sebanyak 40 siswa, 2 ruang kantor guru, 1 ruang direktur, 1 ruang rapat pembantu direktur, 1 ruang kantor tata usaha, 1 ruang tamu, 1 ruang perpustakaan, 1 kantor panitia ujian, 1 kantor P3H, 1 auditorium, 1 kantor HSM, 1 Kantor Hismawati, 1 kantor QNS Banin, 1 kantor QNS Banat, 1 ruang UKS, 1 mushalla, 12 kamar mandi, 1 ruang laboratorium komputer, 1 ruang multi media class, 2 gudang.

Selain itu, perguruan ini juga dilengkapi fasilitas perpustakaan. Sampai saat ini koleksi perpustakaan yang dimiliki Mathali'ul Falah sebanyak 3.209 buku. Namun menurut Bapak Mudhofir, jumlah itu masih jauh dari cukup. Koleksi kurang lengkap dan ruang perpustakaan dianggap kurang pas. Koleksi tersebut meliputi buku-buku berbahasa Arab, Inggris, maupun Indonesia, dengan disiplin ilmu yang beraneka ragam; mulai bahasa, sastra, tafsir, hadits, fiqh, ushul fiqh, serta ilmu-ilmu keislaman 
yang lain. Ada juga koleksi ilmu-ilmu sosial, filsafat, psikologi, pendidikan, ekonomi, dan lain sebagainya.

Laboratorium. Untuk menunjang peningkatkan kemampuan dan skill siswasiswinya, PIM memiliki laboratorium bahasa yang di dalamnya terdapat 20 unit tempat praktikum, 1 buah televisi dan perangkatnya. Melalui laboratorium ini para siswa melakukan eksperimen dan praktik sehingga kemampuan dan skill mereka di bidang bahasa bisa terus meningkat.

Multi Media Class. Di samping laboratorium bahasa, untuk meningkatkan kemampuan siswa-siswinya serta menunjang praktik pengajaran, PIM juga memiliki ruang multi media. Di ruang ini terdapat seperangkat komputer yang dilengkapi dengan LCD, scanner, OHP, Proyektor, VCD \& DVD player, Televisi, Loud Speaker, Air Condition dan didukung dengan daya tampung 40 kursi siswa ditambah 1 kursi tutor.

Auditorium. Selain kegiatan pengajaran, untuk mengembangkan kemampuan sosial dan bakat seni, para siswa mengadakan kegiatan-kegiatan keorganisasian dan kesenian. Auditorium ini adalah ruang serbaguna sebagai sarana yang bisa digunakan oleh para siswa untuk melaksanakan kegiatan-kegiatan mereka.

\section{Perkembangan Santri}

Perkembangan santri baik santri putra (Banin) maupun santri perempuan (Banat) setiap tahunnya mengalami fluktuasi yang relatif tetap. Peserta didik lembaga pendidikan ini kurang lebih berkisar 1800-2100. Terkadang pada jenjang tertentu mengalami penurunan, sedang pada jenjang yang lain mengalami peningkatan. Hal itu bisa dilihat dalam matriks di bawah ini.

Jumlah Santri Perguruan Islam Mathali'ul Falah Kajen Margoyoso Pati

\begin{tabular}{|c|c|c|c|c|c|c|c|}
\hline \multirow{2}{*}{ No. } & \multirow{2}{*}{ Jenjang Pendidikan } & \multicolumn{2}{|c|}{$2012-2013$} & \multicolumn{2}{|c|}{$2013-2014$} & \multicolumn{2}{|c|}{$2014-2015$} \\
\hline & & Lk & $\operatorname{Pr}$ & Lk & $\mathrm{Pr}$ & Lk & $\operatorname{Pr}$ \\
\hline 1 & Madrasah Ibtidaiyah & 72 & 97 & 92 & 101 & 103 & 115 \\
\hline 2 & Madrasah Tsanawiyah & 299 & 427 & 281 & 447 & 305 & 518 \\
\hline 3 & Madrasah Aliyah & 383 & 601 & 330 & 578 & 357 & 627 \\
\hline \multirow{2}{*}{\multicolumn{2}{|c|}{ Jumlah }} & 754 & 1125 & 703 & 1126 & 765 & 1260 \\
\hline & & \multicolumn{2}{|c|}{1879} & \multicolumn{2}{|c|}{1829} & \multicolumn{2}{|c|}{2025} \\
\hline
\end{tabular}

\section{Ketenagaan}

Program muadalah Pesantren Mathali'ul Falah mempunyai tenaga pendidik yang cukup. Rasio santri dengan tenaga pendidik bisa mencapai 1 berbanding 20 . 
Itu artinya tenaga pendidik di pesantren ini cukup memadai. Para guru di samping mengajar di Mathali'ul Falah mereka mempunyai pekerjaan lain sebagai tambahan mereka mencari rezeki.

Di samping mata pelajaran agama, mereka mempunyai guru-guru untuk pelajaran umum seperti guru bahasa Indonesia, Matematika, Ilmu Pengetahuan Alam dan Pendidikan Kewarganegaraan. Para guru pelajaran umum diperoleh pesantren dengan merekrut alumni atau simpatisan pesantren. Sikap para pengelola pesantren Mathaliul Falah terhadap mata pelajaran umum diberikan di kelas, mereka secara umum welcome dan menganggapnya sebagai tambahan pelajaran.

Total jumlah guru dan karyawan di Mathali'ul Falah sebanyak 127 orang. Dari sisi kualifikasi pendidikan, mayoritas guru sudah berpendidikan S1 (Sarjana). Banyak sarjana bergelar Lc yang berarti banyak lulusan dari Timur Tengah. Ada sebagian yang sudah menempuh pendidikan pascasarjana (S2) sebanyak kurang lebih 10 orang, dan yang sudah bergelar Doktor ada satu orang.

\section{Kurikulum}

Perguruan Islam Mathali'ul Falah (PIM) sebagai lembaga pendidikan Islam yang berorientasi pada pengembangan "tafaqquh fi ad-din" (pendalaman ilmu-ilmu agama) dengan ciri-ciri intrinsiknya dan mempersiapkan insan solih dan akrom tentu membutuhkan kurikulum pendidikan yang dapat mewujudkan tujuan yang dimaksud.

Perguruan Islam Mathali'ul Falah (PIM) menerapkan kurikulum yang khas dan unik karena mampu berdiri sendiri. Prosentase perbandingan antara materi agama dan umum adalah 70\% dibanding 30\%. Meskipun demikian, kurikulum PIM selalu merespon setiap perkembangan yang terjadi dan mampu menghasilkan kader-kader yang berkualitas dan aktif dalam pembangunan bangsa.

Pada tingkat Ibtidaiyah dan Tsanawiyah, kurikulum PIM memuat bahan kajian dan pelajaran tentang pendidikan ilmu agama Islam, Pancasila dan Kewarganegaraan, Bahasa Arab, Bahasa Inggris, Bahasa Indonesia, baca tulis Al-Qur'an, Ilmu Pengetahuan Sosial, Matematika serta pengantar sains dan teknologi. Sedangkan isi kurikulum tingkat Aliyah memuat bahan kajian pengembangan dan peningkatan secara kualitatif maupun kuantitatif dari bahan kajian di tingkat Ibtidaiyah dan Tsanawiyah.

Kurikulum perguruan Islam Mathali'ul Falah terdiri dari kurikuler dan non kurikuler. Untuk kurikuler terdiri dari mata pelajaran agama dan mata pelajaran umum. Dalam pengembangan kurikulum, ada yang menarik dari Perguruan Islam Mathali'ul Falah yaitu memasukkan derajat "solih" dan "akrom" dalam pengembangan kurikulum. Nilai solih digunakan sebagai predikat bagi penguasaan ilmu tingkatan tertentu. Sedangkan nilai akrom menjadi nilai penyempurna di atas nilai "solih". 
Secara keseluruhan, semua materi kurikuler dan non kurikuler dikelompokkan dalam lima kategori: (1) materi dasar (basic); (2) Materi Tambahan (Suplemen); (3) Materi Pelengkap (Komplemen); (4) Materi untuk mencapai Solih; (5) Materi untuk mencapai Akrom.

Kurikulum Jenjang Madrasah Ibtidaiyah

\begin{tabular}{|c|l|c|c|c|c|c|}
\hline NO & \multicolumn{1}{|c|}{ MATA PELAJARAN } & BASIC & SUPL & COMP & SOLIH & AKROM \\
\hline 1 & Qiraah Al-Qur'an & $\checkmark$ & & & & $\checkmark$ \\
\hline 2 & Tajwid & & $\checkmark$ & & & $\checkmark$ \\
\hline 3 & Tafsir & $\checkmark$ & & & & $\checkmark$ \\
\hline 4 & Hadits & $\checkmark$ & & & $\checkmark$ & $\checkmark$ \\
\hline 5 & Tauhid & $\checkmark$ & & & & $\checkmark$ \\
\hline 6 & Furu'Fiqh & $\checkmark$ & & & & $\checkmark$ \\
\hline 7 & Pengetahuan Akhlak & $\checkmark$ & & & $\checkmark$ & $\checkmark$ \\
\hline 8 & Imla' & & $\checkmark$ & & $\checkmark$ & \\
\hline 9 & Muhawarah & $\checkmark$ & & & $\checkmark$ & \\
\hline 10 & Nahwu & & $\checkmark$ & & $\checkmark$ & \\
\hline 11 & Sharaf & & $\checkmark$ & & $\checkmark$ & \\
\hline 12 & Qiraah Muthalaah & $\checkmark$ & $\checkmark$ & & & $\checkmark$ \\
\hline 13 & Sejarah Islam & $\checkmark$ & & & $\checkmark$ & \\
\hline 14 & Bhs Indonesia & & & & $\checkmark$ & \\
\hline 15 & Matematika & & & & $\checkmark$ & \\
\hline 16 & IPS & & & & \\
\hline 17 & IPA & & & & \\
\hline 18 & Bhs Daerah & & & & \\
\hline 19 & PPKn & & & & \\
\hline 20 & Bhs Inggris & & & & \\
\hline
\end{tabular}

Pada jenjang Madrasah Ibtidaiyah, konsep "Solih Akrom" diwujudkan dalam sejumlah pelajaran. Khusus penguatan nilai "solih" diterjemahkan dengan penguatan di 14 mata pelajaran seperti yang terlihat dalam matriks. Mata pelajaran yang termasuk ilmu-ilmu umum dan ilmu alat termasuk dalam kategori ilmu "Solih". Selebihnya ilmuilmu yang bermuatan materi agama masuk dalam kategori derajat "akrom" seperti 8 
mata pelajaran (lihat matrik) yang meliputi: Qiraah Al-Qur'an, Tajwid, Tafsir, Hadits, Tauhid, Furu' Fiqh, Pengetahuan Akhlak dan qiraah muthala'ah.

Kurikulum Jenjang Madrasah Tsanawiyah

\begin{tabular}{|c|c|c|c|c|c|c|}
\hline No & MATA PELAJARAI & BASIC & SUPL & COMP & SOLIH & AKROM \\
\hline 1 & Tafsir & $\checkmark$ & & & & $\checkmark$ \\
\hline 2 & Qiraah al Quran & $\checkmark$ & & & & $\checkmark$ \\
\hline 3 & Hadits & $\checkmark$ & & & & $\checkmark$ \\
\hline 4 & Tauhid & $\checkmark$ & & & & $\checkmark$ \\
\hline 5 & Ushul Figh & & $\checkmark$ & & $\checkmark$ & $\checkmark$ \\
\hline 6 & Furu'Fiqh & $\checkmark$ & & & $\checkmark$ & $\checkmark$ \\
\hline 7 & Fiqh Faraid & & $\checkmark$ & & $\checkmark$ & \\
\hline 8 & Pengetahuan Akhlak & $\checkmark$ & & & $\checkmark$ & $\checkmark$ \\
\hline 9 & Nahwu/Sharaf & & $\checkmark$ & & $\checkmark$ & \\
\hline 10 & Balaghah & & $\checkmark$ & & $\checkmark$ & \\
\hline 11 & Insya' & & $\checkmark$ & & $\checkmark$ & \\
\hline 12 & Muhawarah & $\checkmark$ & & & $\checkmark$ & \\
\hline 13 & Qiraah Muthalaah & & $\checkmark$ & & $\checkmark$ & \\
\hline 14 & Falaq & & $\checkmark$ & & $\checkmark$ & \\
\hline 15 & Sejarah Islam & $\checkmark$ & & & $\checkmark$ & $\checkmark$ \\
\hline 16 & Bhs Indonesia & $\checkmark$ & & & $\checkmark$ & \\
\hline 17 & Bhs Inggris & $\checkmark$ & & & $\checkmark$ & \\
\hline 18 & IPS Geografi & & $\checkmark$ & & $\checkmark$ & \\
\hline 19 & IPS Sejarah & & $\checkmark$ & & $\checkmark$ & \\
\hline 20 & IPA & $\checkmark$ & & & $\checkmark$ & \\
\hline 21 & Matematika & $\checkmark$ & & & $\checkmark$ & \\
\hline 22 & PPKn & $\checkmark$ & & & $\checkmark$ & \\
\hline 23 & Administrasi & & $\checkmark$ & & $\checkmark$ & \\
\hline 24 & Ke NU an & $\checkmark$ & & & $\checkmark$ & $\checkmark$ \\
\hline
\end{tabular}

Pada jenjang Tsanawiyah, mata pelajaran umum masuk dalam kategori "Solih", sedangkan Nilai "akrom" pada jenjang Madrasah Tsanawiyah terdapat pada beberapa mata pelajaran seperti: Tafsir, Qiraah Al-Qur'an, Hadits, Tauhid, Ushul Fiqh, Furu' 
Figh, Pengetahuan Akhlak, Sejarah Islam, dan Ke NU an. Pelajaran Ke NU an menjadi pelajaran khusus pada jenjang Tsanawiyah sebagai usaha mengenalkan paham ahlu sunnah wal jamaah dalam dimensi sosial.

Kurikulum Jenjang Madrasah Aliyah

\begin{tabular}{|c|c|c|c|c|c|c|}
\hline NO & MATA PELAJARAN & BASIC & SUPL & COMP & SOLIH & AKROM \\
\hline 1 & Tafsir Al-Qur'an & $\checkmark$ & & & & $\checkmark$ \\
\hline 2 & Ilmu Tafsir & & $\checkmark$ & & & $\checkmark$ \\
\hline 3 & Makharijul Huruf & & $\checkmark$ & & & $\checkmark$ \\
\hline 4 & Ilmu Tashawuf & $\checkmark$ & & & $\checkmark$ & $\checkmark$ \\
\hline 5 & Hadits & $\checkmark$ & & & $\checkmark$ & $\checkmark$ \\
\hline 6 & Musthalah Hadits & & $\checkmark$ & & & $\checkmark$ \\
\hline 7 & Istilah Fuqaha' & & $\checkmark$ & $\checkmark$ & $\checkmark$ & $\checkmark$ \\
\hline 8 & Ushul Fiqh & & $\checkmark$ & & $\checkmark$ & $\checkmark$ \\
\hline 9 & Tarikh Tasyri & & $\checkmark$ & & $\checkmark$ & \\
\hline 10 & Muqaranatul Madzahib & & $\checkmark$ & & $\checkmark$ & \\
\hline 11 & Qawaid Fiqhiyah & & $\checkmark$ & & $\checkmark$ & $\checkmark$ \\
\hline 12 & Muhawarah & $\checkmark$ & & & $\checkmark$ & \\
\hline 13 & Furu'Fiqh & $\checkmark$ & & & $\checkmark$ & \\
\hline 14 & Balaghah & & $\checkmark$ & & $\checkmark$ & \\
\hline 15 & Insya' & & $\checkmark$ & & $\checkmark$ & \\
\hline 16 & Qiraah wal Muthala'ah & & $\checkmark$ & & $\checkmark$ & \\
\hline 17 & Ilmu 'Arudh & & $\checkmark$ & & $\checkmark$ & \\
\hline 18 & IImu Mantiq & & $\checkmark$ & & $\checkmark$ & $\checkmark$ \\
\hline 19 & Ilmu Falaq & & $\checkmark$ & & $\checkmark$ & \\
\hline 20 & SKI & & $\checkmark$ & & $\checkmark$ & \\
\hline 21 & Bhs Indonesia & $\checkmark$ & & & $\checkmark$ & \\
\hline 22 & Bhs Inggris & $\checkmark$ & & & $\checkmark$ & \\
\hline 23 & IPS & & $\checkmark$ & & $\checkmark$ & \\
\hline 24 & PPKn & & $\checkmark$ & & $\checkmark$ & \\
\hline 25 & IPA & $\checkmark$ & & & $\checkmark$ & \\
\hline 26 & Matematika & $\checkmark$ & & & $\checkmark$ & \\
\hline 27 & Administrasi & & $\checkmark$ & & $\checkmark$ & \\
\hline
\end{tabular}




\begin{tabular}{|c|l|c|c|c|c|c|}
\hline NO & \multicolumn{1}{|c|}{ MATA PELAJARAN } & BASIC & SUPL & COMP & SOLIH & AKROM \\
\hline 28 & Ilmu Jiwa & $\checkmark$ & $\checkmark$ & & $\checkmark$ & \\
\hline 29 & Ilmu Pendidikan & $\checkmark$ & & & $\checkmark$ & \\
\hline 30 & Didaktik Metodik & $\checkmark$ & & & $\checkmark$ & \\
\hline
\end{tabular}

Pada jenjang Aliyah ada materi-materi yang hanya diajarkan di jenjang aliyah seperti mata pelajaran ilmu mantiq, qawaid al-Fiqhiyah, ilmu jiwa, ilmu pendidikan dan Didaktik Metodik.

\section{Pembiayaan Pendidikan}

Pembiayaan di Perguruan Islam Mathali'ul Falah mengandalkan kontribusi dari orang tua santri. Untuk menjadi santri pada Mathali'ul Falah,orang tua diharapkan keikhlasannya untuk membayar uang sedekah sebesar Rp. 500.000,- untuk semua jenjang.

Sedangkan kewajiban membayar uang bulanan (syahriyah) untuk jenjang Madrasah Ibtidaiyah sebesar 75.000,-; Madrasah Tsanawiyah Rp. 100.000,-; dan Madrasah Aliyah Rp. 110.000,-. Demikian juga untuk jenjang sekolah persiapan (diniyah), untuk jenjang diniyah ula Rp. 90.000,- dan untuk diniyah wustha Rp. 100.000,--

Akumulasi dari uang yang berasal dari wali santri itu dialokasikan untuk honor guru dan karyawan secara bervariasi. Rata-rata guru/karyawan memdapatkan honor per bulan antara 1 hingga 2 juta menyesuaikan lama pengabdian dan tingkat kontribusi guru/karyawan.

\section{Alumni dan Pengaruh Pesantren Mathali'ul Falah}

Dalam konteks Jawa Tengah, bahkan mungkin juga nasional, pengkaji melihat bahwa keberadaan pesantren Kajen cukup menjadi pusat inspirasi intelektual kalangan nahdliyin. Warna keagamaan yang mendorong pada transformasi sosial telah tumbuh dan mulai berbuah dengan menghasilkan beberapa intelektual muda seperti KH Imam Aziz, Ulil Absar Abdalla, Badriyah Fayumi, Abdul Ghaffar Rozien. Imam Aziz di Yogyakarta mendirikan lembaga Kajian Islam dan Sosial (LKiS), Ulil Abshar Abdalla dikenal --walaupun kontroversial-- sebagai penggagas Jaringan Islam Liberal (JIL), Badriyah Fayumi merupakan anggota DPR yang mengawal kebijakan di bidang Pendidikan, ${ }^{27}$ Abdul Ghaffar Rozien penjaga gawang di Kajen sekaligus

27 Jamal Ma'mur dkk. 2012. Mempersiapkan Insan Sholih Akrom:Potret Sejarah dan Biografi Pendiri-Penerus Perguruan Islam Mathali'ul Falah Kajen Margoyoso Pati 1912-2012. Pati: Perguruan Islam Matholiul Falah. 
direktur Sekolah Tinggi Agama Islam Mathali'ul Falah (STAIMAFA) dan Ketua Umum PP Rabithah Ma'ahid Islamiyah PBNU.

Pesantren Kajen cukup mempunyai warna tersendiri dibandingkan pesantrenpesantren besar dan tua di Jawa Tengah. Misalnya pesantren Sarang Rembang yang mempunyai warna Islam politik karena selalu menjadi referensi bagi Partai Persatuan Pembangunan (PPP); pesantren Al Hikmah Brebes yang bermetamorfosis menjadi pesantren penyelenggara pendidikan modern dari jenjang dasar hingga perguruan tinggi; Pesantren Tegalrejo, Magelang yang menekuni budaya dan tradisi masyarakat akar rumput. Pesantren Kajen menempatkan diri dalam suasana tradisionalisme namun terbuka dalam mengawal perubahan sosial. Posisi ini menjadi cukup unik karena Pesantren Kajen menyemaikan dirinya menjadi pengawal gagasan Islam transformatif berbasis tradisionalisme Islam. 